\title{
Antibiotic use in chicken farms in northwestern China
}

Jingyi $\mathrm{Xu}^{1,2}$, Rassamee Sangthong ${ }^{2^{*}}$, Edward McNeil ${ }^{2}$, Rong Tang ${ }^{1}$ and Virasakdi Chongsuvivatwong ${ }^{2}$

\begin{abstract}
Background: Misuse of antibiotics in food animals contributes to an increase of antibiotic resistant bacteria transmitting to humans. China is the largest producer and user of antibiotics in the world, of which animals share more than half of the total consumption. This study aimed to explore Chinese farmer's practice of antibiotic use and the factors associated with their use.

Methods: In this cross-sectional survey, we interviewed farmers from 88 chicken farms in northwestern China. We defined two kinds of misuse: 1) using antibiotics in the Chinese prohibited list, and 2) using antibiotics within the recommended withdrawal period. Factor analysis was used to select farmers' knowledge variables and multinomial logistic regression was used to determine factors associated with antibiotic misuse.
\end{abstract}

Results: All the participating farmers used antibiotics on their farms. Amoxicillin was the most common antibiotic used (76.5\%), followed by norfloxacin, ofloxacin, ceftriaxone and oxytetracycline. $75 \%$ of farmers used antibiotics in the prohibited list while $14.8 \%$ continued to use antibiotics during the withdrawal period. Hierarchical cluster analysis revealed three patterns of antibiotic use: 1) excessive use of non-prohibited and prohibited antibiotics or an excessive user, 2) low use of a few types of non-prohibited and moderate use of prohibited antibiotics or a low user, 3) multiple use of a variety ( $\geq 7$ types) of non-prohibited and prohibited antibiotics or a moderate user. Farmers from medium size, family-based farms, those with a low education level and low income were more likely to misuse antibiotics. Prior formal agricultural training was associated with reducing multiple types of antibiotic use. There was a huge gap between policy and reinforcement causing antibiotic misuse in the study community.

Conclusion: Antibiotics are commonly used on chicken farms; misuse of antibiotics is high; improvement in farm sanitation, education on antibiotic use for farmers and veterinarians/pharmacists and enforcement of the regulations may reduce antibiotic use on chicken farms in China.

Keywords: Antibiotic resistance, Chicken farm, Patterns of antibiotic use, Factors of misuse, One health

\section{Background}

China's economic growth in the past three decades has changed its agriculture system from a traditional backyard approach into intensive animal production. As a result, China has become the largest producer and user of antibiotics in the world, and animals share more than half of the total consumption $[1,2]$. This high rate of antibiotic use has an important impact on the emergence of resistant bacteria transmitted between animals and humans by direct contact, food borne or indirect contamination

\footnotetext{
*Correspondence: rassamee.s@psu.ac.th

${ }^{2}$ Epidemiology Unit, Faculty of Medicine, Prince of Songkla University, Hat

Yai, Songkhla 90110, Thailand

Full list of author information is available at the end of the article
}

through the environment $[1,3,4]$. Eventually, it poses an increasingly serious threat to public health [5].

The Chinese government has made a series of efforts to control antibiotic use in animals. For example, it has successively released a prohibited list of antibiotics not to be used in farming, banned antibiotic use during withdrawal periods, classified management of prescription drugs and over-the-counter drugs, forbidden the use of medically important drugs such as cephalosporin class in animals, and required farmers to record their antibiotic use [6-9]. Nevertheless, the estimated use of antibiotics in food animals is still alarming as indicated by the increasing amount of manure pollution; 227 million tons were recorded in 2010 and it is estimated to be 298 million tons

(c) The Author(s). 2020 Open Access This article is distributed under the terms of the Creative Commons Attribution 4.0 International License (http://creativecommons.org/licenses/by/4.0/), which permits unrestricted use, distribution, and reproduction in any medium, provided you give appropriate credit to the original author(s) and the source, provide a link to the Creative Commons license, and indicate if changes were made. The Creative Commons Public Domain Dedication waiver (http://creativecommons.org/publicdomain/zero/1.0/) applies to the data made available in this article, unless otherwise stated. 
in 2020 [10]. Without any effective control, antibiotic consumption in chickens is expected to increase by $143 \%$ from 2010 to 2030 [10].

Previous studies mostly examined antibiotic resistant microbial strains and resistance patterns $[11,12]$ while antibiotic use on chicken farms is highly related to farmers' knowledge and attitude [13, 14]. Understanding farmers' antibiotic use and their justification for the use can help reduce the problems. This study aimed to explore farmer's practice of antibiotic use and determine the factors associated with antibiotic misuse in northwestern China.

\section{Methods}

\section{Study setting and sampling}

A survey was conducted in all 5 regions in Ningxia province, northwestern China. Each region has a high concentration of livestock (total number of chickens is more than one million according to government statistical documents) [15]. Probability proportional to size sampling was employed to select the farms. Eventually, 88 commercial chicken farms with at least 500 chickens/farm were selected at random. One farmer who was responsible for antibiotic use on the farm was invited to participate in the study.

\section{Data collection}

A structured questionnaire comprising 4 main sections was developed: 1) farm characteristics and information on farming management procedures, 2) sociodemographic characteristics of farmers, 3) farmers' practice of chicken disease prevention and infection control (13 common diseases in chickens, 9 types of common vaccinations and 20 types of antibiotics generally administered by farmers were listed in questionnaire) and 4) farmer's knowledge of and attitudes to antibiotic use. Sections Results and Discussion were validated by two veterinarians and two medical doctors who subspecialized in infectious diseases and antibiotic use. The questionnaire was developed and tested in a non-study village but similar to one in the study setting.

Three trained researchers visited the selected farms and invited a responsible farmer (owner /manager) of the farm, to participate in the study. Written informed consent was obtained from all farmers after they agreed to participate in the study. The questionnaires were self-completed and each questionnaire took about $30 \mathrm{~min}$ to complete.

This study was approved by the ethical review committee of Ningxia Medical University, China and the Faculty of Medicine, Prince of Songkla University, Thailand.

\section{Data management and analysis}

EpiData 3.1 [16] was used for data entry. Descriptive statistics were used to examine characteristics of the study farms and farmers. The farms were classified into 3 size categories based on the total number of chickens: small $(<10,000)$, medium $(10,000-100,000)$, and large $(>100,000)$. According to the Chinese agriculture department's regulations for food animals and animal health organization guideline [8, 17], misuse of antibiotics was defined as use of any antibiotic on the prohibited list and/or within the withdrawal period. Withdrawal period refers to the minimum time that must pass after the last administration of veterinary medicine before the animal can enter the food supply, to ensure that no residues remain in the meat or the products [18].

Hierarchical heat map analysis was used to illustrate patterns of antibiotic use based on clustering types of antibiotics and frequency of antibiotic used. Factor analysis on knowledge about antibiotic use and antibiotic resistance was performed to reduce the number of variables and used for model adjustment. Multinomial logistic regression was used to examine associated factors for antibiotic use. All data analysis was done using R 3.5.2 [19].

\section{Results}

A total of 88 farmers from 88 farms agreed to participate in the study for a response rate of $100 \%$.

\section{Farm characteristics}

Table 1 shows characteristics of the study farms, the respondents and antibiotic misuse. Most farms (94\%) were small and medium sized, identified as a family business farm with a small number of employees, and raised layer chickens. Most farmers had more than 10 years' experiences in farming. One-third of the farms used sanitary chicken houses and the other two-thirds still used soil feedlots. All farms used commercial feeds, the majority of which were premixed and concentrated. Most farms directly discarded their waste products into the environment without any purification. Most farmers were male, middle aged, married and completed a lower school level of education. Few had any formal training in animal husbandry. One-third of farmers' families earned less than 5000 yuan per month.

Overall, $78.4 \%$ of farmers misused antibiotics; $75.0 \%$ used antibiotics from the prohibited list, 14.8\% used antibiotics during the withdrawal period, and $11 \%$ did both. Small and medium sized farms, those that had been operating for more than 20 years, and those with poor sanitation had higher rates of antibiotics misuse.

Female and younger farmers were more likely to use antibiotics both in the prohibited list and during the withdrawal period while non-married farmers, those with a higher education level and with higher incomes had lower rates of antibiotic misuse. Farmers with formal training had a lower rate of antibiotic misuse while those who had more than 20 years of farming experience were more likely to misuse antibiotics.

\section{Common infectious diseases and infection control methods among farmers}

Table 2 shows the distribution of disease and infection control methods used by farmers from the 88 study farms. 
Table 1 Characteristics of farms and baseline demographic data of farmers by types of antibiotic misuse $(N=88)$

\begin{tabular}{|c|c|c|c|c|c|}
\hline \multirow[t]{2}{*}{ Characteristics } & \multirow{2}{*}{$\begin{array}{l}\text { Total N } \\
\text { (\%) }\end{array}$} & \multirow{2}{*}{$\begin{array}{l}\text { Appropriate } \\
\text { use N (\%) }\end{array}$} & \multicolumn{3}{|l|}{ Misuse, N (\%) } \\
\hline & & & Prohibited only & Withdrawal only & Both types \\
\hline Total, N (\%) & $88(100)$ & $19(21.6)$ & $56(63.6)$ & $3(3.4)$ & $10(11.4)$ \\
\hline \multicolumn{6}{|l|}{ Farm } \\
\hline \multicolumn{6}{|l|}{ Size } \\
\hline Small & $49(55.7)$ & $10(52.6)$ & $30(53.6)$ & $1(33.3)$ & $8(80.0)$ \\
\hline Medium & $34(38.6)$ & $5(26.3)$ & $25(44.6)$ & $2(66.7)$ & $2(20.0)$ \\
\hline Large & $5(5.7)$ & $4(21.1)$ & $1(1.8)$ & 0 & 0 \\
\hline \multicolumn{6}{|l|}{ Types of farm } \\
\hline Family & $81(92.0)$ & $14(73.7)$ & $54(96.4)$ & $3(100)$ & $10(100)$ \\
\hline Factory & $7(8.0)$ & $5(26.3)$ & $2(3.6)$ & 0 & 0 \\
\hline \multicolumn{6}{|c|}{ Number of workers (person) } \\
\hline$\leq 3$ & $69(78.4)$ & $12(63.2)$ & $46(82.1)$ & $2(66.7)$ & $9(90.0)$ \\
\hline$>3$ & 19 (21.6) & $7(36.8)$ & $10(17.9)$ & $1(33.3)$ & $1(10.0)$ \\
\hline \multicolumn{6}{|l|}{ Farm duration (years) } \\
\hline$<10$ & $17(19.3)$ & $7(36.8)$ & $7(12.5)$ & 0 & $3(30.0)$ \\
\hline $10-19$ & $55(62.5)$ & $11(57.9)$ & $37(66.1)$ & $2(66.7)$ & $5(50.0)$ \\
\hline$\geq 20$ & 16 (18.2) & $1(5.3)$ & $12(21.4)$ & $1(33.3)$ & $2(20.0)$ \\
\hline \multicolumn{6}{|l|}{ Species of chicken } \\
\hline Layer & $63(71.6)$ & $15(78.9)$ & $37(66.1)$ & $3(100)$ & $8(80.0)$ \\
\hline Broiler & $23(26.1)$ & $4(21.1)$ & $18(32.1)$ & 0 & $1(10.0)$ \\
\hline Hatchery & $2(2.3)$ & 0 & $1(1.8)$ & 0 & $1(10.0)$ \\
\hline \multicolumn{6}{|l|}{ Types of feedlots } \\
\hline Soil feedlots & $60(68.2)$ & $9(47.4)$ & $42(75.0)$ & $2(66.7)$ & $7(70.0)$ \\
\hline Sanitary house & $28(31.8)$ & $10(52.6)$ & $14(25.0)$ & $1(33.3)$ & $3(30.0)$ \\
\hline \multicolumn{6}{|l|}{ Feed type } \\
\hline Premixed & $43(48.9)$ & $11(57.9)$ & $22(39.3)$ & $3(100)$ & $7(70.0)$ \\
\hline Concentrated & $40(45.5)$ & $6(31.6)$ & $31(55.4)$ & 0 & $3(30.0)$ \\
\hline Complete & $5(5.7)$ & $2(10.5)$ & $3(5.4)$ & 0 & 0 \\
\hline \multicolumn{6}{|l|}{ Waste treatment } \\
\hline Send to field & $71(80.7)$ & $11(57.9)$ & $51(91.1)$ & $1(33.3)$ & $8(80.0)$ \\
\hline Compost or Methane & $17(19.3)$ & $8(42.1)$ & $5(8.9)$ & $2(66.7)$ & $2(20.0)$ \\
\hline \multicolumn{6}{|l|}{ Farmer: owner/ manager } \\
\hline \multicolumn{6}{|l|}{ Gender } \\
\hline Male & $67(76.1)$ & $15(78.9)$ & $42(75.0)$ & $3(100)$ & $7(70.0)$ \\
\hline Female & $21(23.9)$ & $4(21.1)$ & $14(25.0)$ & 0 & $3(30.0)$ \\
\hline \multicolumn{6}{|l|}{ Age (years old) } \\
\hline $18-45$ & $24(27.3)$ & $5(26.3)$ & $12(21.4)$ & $2(66.7)$ & $5(50.0)$ \\
\hline$>45$ & $64(72.7)$ & $14(73.7)$ & 44 (78.6) & $1(33.3)$ & $5(50.0)$ \\
\hline \multicolumn{6}{|l|}{ Marital status } \\
\hline Married & $74(84.1)$ & $13(68.4)$ & $48(85.7)$ & $3(100)$ & $10(100)$ \\
\hline Not-married & 14 (15.9) & $6(31.6)$ & $8(14.3)$ & 0 & 0 \\
\hline \multicolumn{6}{|l|}{ Education } \\
\hline Primary & 16 (18.2) & $2(10.5)$ & $13(23.2)$ & 0 & $1(10.0)$ \\
\hline Secondary & 47 (53.4) & $7(36.8)$ & 33 (58.9) & $1(33.3)$ & $6(60.0)$ \\
\hline
\end{tabular}


Table 1 Characteristics of farms and baseline demographic data of farmers by types of antibiotic misuse $(N=88)(C o n t i n u e d)$

\begin{tabular}{|c|c|c|c|c|c|}
\hline \multirow[t]{2}{*}{ Characteristics } & \multirow{2}{*}{$\begin{array}{l}\text { Total N } \\
\text { (\%) }\end{array}$} & \multirow{2}{*}{$\begin{array}{l}\text { Appropriate } \\
\text { use N (\%) }\end{array}$} & \multicolumn{3}{|l|}{ Misuse, N (\%) } \\
\hline & & & Prohibited only & Withdrawal only & Both types \\
\hline$\geq$ high school & $25(28.4)$ & $10(52.6)$ & $10(17.9)$ & $2(66.7)$ & $3(30.0)$ \\
\hline \multicolumn{6}{|c|}{ Family income/month (yuan) } \\
\hline$<5000$ & $32(36.4)$ & $5(26.3)$ & $19(33.9)$ & $1(33.3)$ & $7(70.0)$ \\
\hline$\geq 5000$ & $56(63.6)$ & $14(73.7)$ & $37(66.1)$ & $2(66.7)$ & $3(30.0)$ \\
\hline \multicolumn{6}{|c|}{ Professional farm training } \\
\hline No & $50(56.8)$ & $8(42.1)$ & $34(60.7)$ & $1(33.3)$ & $7(70.0)$ \\
\hline Yes & $38(43.2)$ & $11(57.9)$ & $22(39.3)$ & $2(66.7)$ & $3(30.0)$ \\
\hline \multicolumn{6}{|c|}{ Farming experience (years) } \\
\hline$<10$ & $16(18.2)$ & $5(26.3)$ & $8(14.3)$ & 0 & $3(30.0)$ \\
\hline $10-19$ & $31(35.2)$ & $8(42.1)$ & 19 (33.9) & $1(33.3)$ & $3(30.0)$ \\
\hline$\geq 20$ & $41(46.6)$ & $6(31.6)$ & $29(51.8)$ & $2(66.7)$ & $4(40.0)$ \\
\hline
\end{tabular}

Note: Prohibited means misusing antibiotics in the government prohibited list for food animals

Withdrawal means misusing antibiotics during the withdrawal period

The five most common diseases were Escherichia coli bacterial infection, avian influenza, avian infectious laryngotracheitis, Newcastle disease and pullorum disease. Almost 90\% of farmers immunized their chickens in combination with the use of traditional Chinese medicine. Antibiotics played an important role for prevention and/or treatment but were rarely used for growth promotion. About $15 \%$ of farmers used antibiotics during the withdrawal period, mostly due to detection of clinical signs of infection, and $75 \%$ used antibiotics from the prohibited list. About $81 \%$ of farmers purchased antibiotics from a veterinary drug store while the rest did so from a pharmacy store, online or feed factory. More than half purchased antibiotics without a prescription. Only one-third of the farmers recorded their antibiotic use. According to some farmers' records, the antibiotics were regularly used in a cyclical pattern of continuous use followed by a period of discontinued use. Farmers mixed antibiotics into either water or feed together with some Chinese traditional medicine, or alternately used some herbal compounds, such as astragalus polysaccharide, for disease prevention. Some farmers commonly changed antibiotic types to decrease the rate of antibiotic resistance.

\section{Patterns of antibiotic use}

A hierarchical heat map of antibiotic use pattern among the 88 farms is shown in Fig. 1. Amoxycillin, oxytetracycline and ceftriaxone were the most commonly used antibiotics while ofloxacin and norfloxacin were the second most common antibiotics used. Hierarchical cluster analysis (dendrogram of farms) revealed three patterns of antibiotic use based on the distribution of antibiotics used in each farm. The first pattern (upper part) was characterized by excessive use of non-prohibited and prohibited antibiotics. The second pattern (middle part) was characterized by low use of relatively few types of non-prohibited and moderate use of prohibited antibiotics. The third pattern (lower part) was characterized by multiple use of a variety $(\geq 7)$ of both prohibited and non-prohibited antibiotics. The farms can be classified as excessive users, low users and moderate users according to the three patterns.

\section{Farmers' knowledge of antibiotics and antibiotic resistance in food animals}

As a whole, farmers had a good knowledge about safe antibiotic use, adverse reactions and antibiotic resistance in chickens. However, they were not aware of differences between viral and bacterial infections and only about one-third knew that inappropriate use of antibiotics in chickens could lead to antibiotic resistance in human bacteria (Table 3).

\section{Factors associated with farmers' antibiotic misuse in food animals}

Table 4 shows that farmers with a secondary or higher level of education and high income were less likely to misuse antibiotics (Pattern I) compared to farmers with a primary school level of education and low income, respectively. Farmers from a medium sized farm were more likely to misuse antibiotics compared to those from small farms. Farmers who had formal agricultural training had a lower odds of multiple antibiotic misuse (Pattern III).

\section{Discussion}

This study examined 88 farmers' practice of antibiotic use on chicken farms in high density agricultural areas in Northwestern China. All the farmers used antibiotics on their farms (Some farmers did not report types of antibiotics used as they did not always know the types of antibiotics or used antibiotics other than those mentioned in the study). Amoxicillin was the most commonly used antibiotic (76.5\%), 
Table 2 Disease and infection control methods among farmers $(N=88)$

\begin{tabular}{|c|c|}
\hline Variables & $n(\%)$ \\
\hline \multicolumn{2}{|l|}{ Top 5 diseases } \\
\hline Escherichia coli infection & $65(73.9)$ \\
\hline Avian influenza ${ }^{a}$ & $60(68.2)$ \\
\hline Avian infectious laryngotracheitis ${ }^{a}$ & $41(46.6)$ \\
\hline Newcastle disease ${ }^{a}$ & $37(42.0)$ \\
\hline Pullorum disease & $36(40.9)$ \\
\hline \multicolumn{2}{|l|}{ Use of vaccination } \\
\hline Compulsory (> 1 type) & $79(89.8)$ \\
\hline Optional (> 2 types) & $79(89.8)$ \\
\hline Use of traditional Chinese medicine & $77(87.5)$ \\
\hline Use of antibiotics & $86(97.7)$ \\
\hline Use of antibiotics during withdrawal periods & $13(14.8)$ \\
\hline Use of antibiotics on the prohibited list & $66(75.0)$ \\
\hline \multicolumn{2}{|l|}{ Primary purpose of antibiotic use } \\
\hline Prevention & $43(48.9)$ \\
\hline Treatment & $22(25.0)$ \\
\hline Both prevention and treatment & $22(25.0)$ \\
\hline Growth promotion & $1(1.1)$ \\
\hline \multicolumn{2}{|l|}{ Frequency of antibiotic use } \\
\hline Occasionally & $54(61.4)$ \\
\hline Regularly & $34(38.6)$ \\
\hline \multicolumn{2}{|l|}{ Common route of antibiotic administration } \\
\hline Mixed with food and/or water & $86(97.7)$ \\
\hline Injection or forced feeding & $9(10.2)$ \\
\hline Kept a record of antibiotic use & $33(37.5)$ \\
\hline Able to purchase antibiotics without a prescription & $52(59.1)$ \\
\hline \multicolumn{2}{|l|}{ Sources of drugs } \\
\hline Veterinary drug store & $71(80.7)$ \\
\hline Pharmacy store/Online/Feed factory & $16(18.2)$ \\
\hline
\end{tabular}

followed by norfloxacin, ofloxacin, ceftriaxone and oxytetracycline. Antibiotic use could be classified into 3 patterns: 1) excessive use of non-prohibited and prohibited antibiotics or an excessive user, 2) low use of a few types of nonprohibited and moderate use of prohibited antibiotics or a low user, 3) multiple use of a variety ( $\geq 7$ types) of nonprohibited and prohibited antibiotics or a moderate user.75\% of farms used antibiotics on the prohibited list while 14.8\% continued to use antibiotics during the withdrawal period. Farmers from medium sized, family-based farms, those with a low education level and lower income were more likely to misuse antibiotics. Prior formal agricultural training was associated with lower odds of using multiple types of antibiotics.

\section{Famers' practice of antibiotic use}

The most common infection on chicken farms was Escherichia coli infection followed by three viral diseases. Most farmers immunized their chickens with compulsory and optional vaccines, and used traditional medicine as well as antibiotics. Antibiotics were excessively used for infection prevention rather than treatment. Similarly, the use of antibiotics for prevention was also reported on large chicken farms in other developing countries such as Vietnam and Thailand $[20,21]$. Use of antibiotics for preventing infections is not in compliance with the recommendations of the U.S. Food and Drug Administration [22].

Farmers included in the study can easily access and purchase antibiotics from local drug stores, online, and feed factories with or without prescription. The accessibility of antibiotics has a strong influence on farmers' decision making [23], therefore, veterinarians/pharmacists also played critical roles in antibiotic use and misuse. In fact, Chinese regulations published in 2013, state that all antibiotics require prescription and only licensed veterinarians can prescribe antibiotics [17]. Furthermore, only one-third of farmers recorded their antibiotic use as instructed by the government. Lack of data and monitoring makes it difficult to manage and therefore reduce the problem.

Among the five most popular antibiotics used in this study, only amoxycillin and oxytetracycline are allowed to be used. Although these two antibiotics were considered to have a lower risk and are most commonly used on chicken farms worldwide [20,21, 24], frequent and regular use can accelerate the resistance process [5, 25]. Previous studies have reported high rates of resistance to amoxicillin and oxytetracycline in poultry in China and other countries $[11,26,27]$. This eventually leads farmers to use higher level of medically important antibiotics or other antibiotics on the prohibited list $[28,29]$.

Regardless of the regular use of non-prohibited antibiotics, three-quarters of farmers used prohibited antibiotics. One objective of farmers to use different antibiotics was to decrease the risk of development of resistance in bacteria from chickens. However, they were unaware that this may lead to multiple resistant bacterial strains in both animals and human [28-30]. Antibiotics on the prohibited list have been determined as unsafe drugs and their use has been banned by the Chinese government [8]. Although these drugs were preferable among our study farmers (their use improved their chicken production leading to economic profits), neglecting the consequences to human health can lead to high mortality rates because of antibiotic resistance.

Using antibiotics as a growth promotor is a serious problem worldwide, but it was rarely reported in our study. Even though the use of antibiotics as growth promoters is banned in many developed countries [6,31], China does not have any restrictions over the direct use of antibiotics as growth 
Level of prevalence of antibiotic use

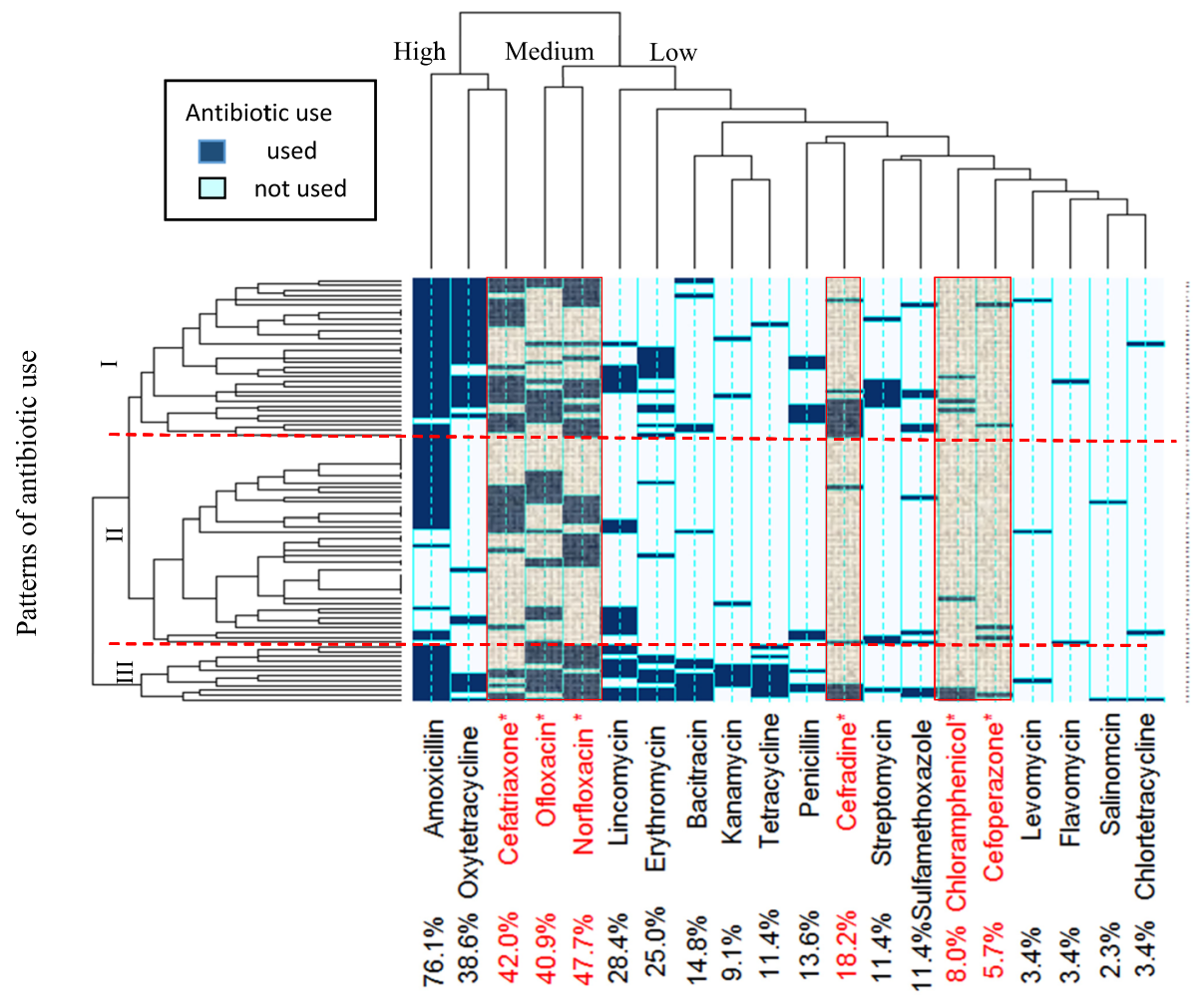

Prevalence of antibiotic use by type (\%)

Fig. 1 Heat map showing patterns of antibiotic use in 88 farms. * Antibiotics in the national agriculture prohibited list for food animal (Columns with shadow). High, Medium, Low refer to antibiotic use levels from the most popular group to less popular group. Separated by dash line are the three patterns of antibiotic use: I- Excessive use of non-prohibited and prohibited antibiotics or an excessive user. II- Low use of a few types of non-prohibited and moderate use of prohibited antibiotics or a low user. III- Multiple use of a variety ( $\geq 7$ types) of non-prohibited and prohibited antibiotics or a moderate user

promoters. Recently, however, the Ministry of Agriculture approved 21 antibiotic products that may be added as growth promoters in commercial feeds [8]. Previous studies reported high concentrations of several antibiotics in animal commercial feeds in China [12, 32]. Our study found that all farmers used commercial feeds on their farms. Thus, they may have unknowingly used growth promoters. Lowdoses of prolonged courses of antibiotics used in food

Table 3 Farmers' knowledge of antibiotics and antibiotic resistance in food animals

\begin{tabular}{|c|c|c|c|c|}
\hline \multirow[t]{2}{*}{ Question/Statement } & \multicolumn{3}{|c|}{ Answer, n (\%) } & \multirow{2}{*}{$\begin{array}{l}\text { Correct } \\
\text { Answer }\end{array}$} \\
\hline & Yes & No & I don't know & \\
\hline Do you know the withdrawal period for antibiotic drugs used in chickens? & $76(86.4)$ & $11(12.5)$ & $1(1.1)$ & $76(86.4)$ \\
\hline Antibiotics are safe when used routinely. & $4(4.5)$ & $72(81.8)$ & $12(13.6)$ & $72(81.8)$ \\
\hline Do you know that animals develop antibiotic resistant bacteria? & $67(76.1)$ & $4(4.5)$ & $17(19.3)$ & $67(76.1)$ \\
\hline Antibiotics can cause unwanted or adverse reactions. & $65(73.9)$ & $7(8.0)$ & $16(18.2)$ & $65(73.9)$ \\
\hline Do you know about antibiotic resistance? & $65(73.9)$ & $18(20.5)$ & $5(5.7)$ & $65(73.9)$ \\
\hline Very frequent antibiotic use can reduce its effect? & $64(72.7)$ & $6(6.8)$ & $18(20.5)$ & $64(72.7)$ \\
\hline Are you concerned about antibiotic resistance? & $62(70.5)$ & $11(12.5)$ & $15(17.0)$ & $62(70.5)$ \\
\hline Antibiotics can improve the immunity of chickens. & $15(17.0)$ & $57(64.8)$ & $16(18.2)$ & $57(64.8)$ \\
\hline Antibiotics can cure bacterial infections. & $40(45.5)$ & $19(21.6)$ & $29(33.0)$ & $40(45.5)$ \\
\hline Antibiotics can cure viral infections. & $20(22.7)$ & $39(44.3)$ & $29(33.0)$ & $39(44.3)$ \\
\hline Antibiotic resistant bacteria can spread among animals and humans. & $31(35.2)$ & $32(36.4)$ & $25(18.4)$ & $31(35.2)$ \\
\hline
\end{tabular}


Table 4 Distribution of estimated independent variables predicting antibiotic misuse patterns (Multinomial regression with appropriate use of antibiotics as reference category)

\begin{tabular}{|c|c|c|c|}
\hline \multirow[t]{3}{*}{ Variable } & \multicolumn{3}{|l|}{ Misuse } \\
\hline & Pattern I & Pattern II & Pattern III \\
\hline & $\operatorname{RRR}(95 \% \mathrm{Cl})$ & $\operatorname{RRR}(95 \% \mathrm{Cl})$ & $\operatorname{RRR}(95 \% \mathrm{Cl})$ \\
\hline \multicolumn{4}{|l|}{ Education level } \\
\hline Primary & ref. & ref. & ref. \\
\hline Secondary & $0.06(0,0.88) *$ & $0.37(0.02,6.25)$ & $0.18(0.01,4.31)$ \\
\hline$\geq$ High school & $0.01(0,0.3) * *$ & $0.07(0,1.56)$ & $0.40(0.02,9.64)$ \\
\hline \multicolumn{4}{|l|}{ Gender } \\
\hline Male & ref. & ref. & ref. \\
\hline Female & $0.83(0.15,4.54)$ & $0.52(0.09,2.99)$ & $0.72(0.1,5.39)$ \\
\hline \multicolumn{4}{|c|}{ Family income /month (yuan) } \\
\hline$<5000$ & ref. & ref. & ref. \\
\hline$\geq 5000$ & $0.08(0.01,0.68) *$ & $0.16(0.02,1.10)$ & $0.39(0.04,3.56)$ \\
\hline \multicolumn{4}{|c|}{ Formal farming training } \\
\hline No & ref. & ref. & ref. \\
\hline Yes & $1.14(0.24,8.27)$ & $0.91(0.18,4.70)$ & $0.08(0.01,0.79) *$ \\
\hline \multicolumn{4}{|c|}{ Knowledge of risks } \\
\hline Median (IQR) & $2.81(0.98,8.04)$ & $2.63(0.96,7.22)$ & $2.34(0.73,7.55)$ \\
\hline \multicolumn{4}{|l|}{ Farm size } \\
\hline Small & ref. & ref. & ref. \\
\hline Medium & $8.2(1.31,51.19) *$ & $1.92(0.37,10.07)$ & $1.77(0.24,13.11)$ \\
\hline Large & $0(0)$ & $0(0)$ & $0.08(0,2.03)$ \\
\hline
\end{tabular}

${ }^{*} P<0.05 ;{ }^{* *} P<0.01 ; C l$ Confidence interval, RRR Relative risk ratio. IQR Interquartile range, Ref Reference group. Pattern I: Excessive use of prohibited antibiotics; Pattern II: Moderate use of prohibited antibiotics; Pattern III: Use of many kinds of prohibited antibiotics

animals create ideal circumstances for emergence of resistant strains in animals [33].

Majority farmers (86\%) knew withdrawal period, but still part of them did not adhere to the rules. This may due to their vulnerable economy and the absence of government residual detections. However, the prevalence rate of using antibiotics within withdrawal period was not much high (14.8\%), compared to other similar studies, like Cameroon poultry farms $(49.6 \%)$ and Cambodian pig farms (47\%) [24,
34]. Therefore, our heat map analysis focused on the prohibited antibiotic use other than withdrawal period misuse.

The pattern of use and misuse of antibiotics in food animals can highlight the implications of the emergence of different types of antibiotic resistant bacteria and their dissemination among animals, humans and the environment. The situation has been reported in many previous studies from multiple countries, which have initiated the One Health approach for better understanding and addressing health issues around the world [30, 35-37].

\section{Factors associated with misuse of antibiotics}

Factors associated with increased misuse of antibiotics included medium farm size, lower education levels, lower farmer's income and lack of formal agricultural training. Medium-sized farms in our study had poor sanitation but a very intensive production model which increased the risk of infection and thus higher antibiotic use. Good hygiene, cleanliness and waste management on large farms consistently yielded reports of low use of antibiotics not only in our study but in other studies as well [27, 38, 39]. Farmers with a higher education, especially above high school, were less likely to misuse antibiotics. In both developed and developing countries, education is important for farmers to comply with the national guidelines $[23,39,40]$. Low income farmers may be more anxious about infection and thus used more antibiotics to prevent and control infections [23, 41]. The descriptive findings on knowledge about antibiotic and antibiotic resistance revealed that most farmers were unaware of differences between bacterial and viral infections. The majority of them thought that antibiotics were a panacea for all types of disease. Moreover, only one-third of the farmers knew about the potential for antibiotic resistance transmission from animals to humans. This is also the case for farmers in other developing countries such as Cambodia [14, 35]. In contrast farmers from developed countries such as Germany have a higher level of awareness of the possible transmission between animals and humans [42]. Training in pharmaceutical knowledge and antibiotic stewardship will reduce the prevalence of multiple antibiotic use $[5,13,14]$.

Table 5 Regulations related to antibiotic use in food animals vs findings in this study

\begin{tabular}{ll}
\hline Regulation & Facts in this study \\
\hline - Use of any antibiotic included in the prohibited list is & $-75 \%$ of farms used prohibited antibiotics in chickens. \\
forbidden. & \\
- Use of antibiotics during the withdrawal period is & $-15 \%$ of farms extended antibiotic use into the withdrawal period. \\
forbidden. & \\
- Purchase of antibiotics without a veterinary prescription & $-59 \%$ of farmers were able to purchase antibiotics without a prescription. \\
is forbidden. & \\
- Use of medically important antibiotics in food animals is & - Use of medically important antibiotics, such as the cephalosporin class, was found \\
forbidden. & on chicken farms. \\
- Farmers should record their antibiotic use. & $-62.5 \%$ of farmers did not record their antibiotic use. \\
\hline
\end{tabular}




\section{Policy vs reality}

The Chinese government has taken a series of actions to control antibiotic resistance over the past two decades, and published regulations to restrict antibiotic use in food animals. However, the gap between policy and reality can been seen in Table 5. The enforcement of the regulations is deemed an urgent issue.

\section{Limitations}

Some practices against national regulations might have been under-reported, for example using the antibiotics in the prohibited list or using antibiotics during the withdrawal period. Due to a lack of knowledge among farmers, some farmers did not report the types of antibiotics used, which may have underestimated the antibiotic use reported in this study.

\section{Conclusions}

Chinese farmers use large quantities of antibiotics on poultry farms and the misuse is also high. Although national regulations to control antibiotic use are available, they are not well enforced. Improving farm sanitation, especially on small and medium sized farms, providing training about appropriate antibiotic use to farmers, educating veterinarians/pharmacists to protect the health of both animals and humans, restricting free availability as well as enforcing the national regulations may lower antibiotic misuse and decelerate the problem.

\section{Abbreviations}

FAO: U.S. Food and Drug Administration; WHO: World Health Organization

\section{Acknowledgements}

The authors would like to acknowledge the support of Prince of Songkla University and Ningxia Medical University and all the participants.

\section{Authors' contributions}

JX, RS, VC conceived and designed the study and reviewed the manuscript. JX collected and analyzed the data and wrote the manuscript. EM analyzed data and reviewed the manuscript. RT collected data and reviewed the manuscript. All authors read and approved the final manuscript.

\section{Funding}

This study is part of the first author's thesis in partial fulfillment of the requirements for a Ph.D. at Prince of Songkla University, Thailand, and the China Medical Board under the project of "A Second Collaborative Program to Improve the Health Research Capacity of Western Medical Universities in China and Prince of Songkla University (PSU)." This study is also funded by Top Discipline of Public Health and Prevent Medicine (NXYLXK2017A07), Education Department of Ningxia, China.

\section{Availability of data and materials}

All relevant materials and data supporting the findings of this study are contained within the manuscript.

\section{Ethics approval and consent to participate}

This study was approved by the ethical review committee of Ningxia Medical University, China (NO.2018107) and the ethical review committee of the Faculty of Medicine, Prince of Songkla University, Thailand (REC:60336181). All farmers were informed about the purpose of the study. Informed consent was obtained from each participant before the interviews.
Consent for publication

Not applicable.

\section{Competing interests}

The authors declare that they have no competing interests.

\section{Author details}

${ }^{1}$ Public Health and Management Faculty, Ningxia Medical University, Yinchuan, Ningxia, China. 'Epidemiology Unit, Faculty of Medicine, Prince of Songkla University, Hat Yai, Songkhla 90110, Thailand.

Received: 5 June 2019 Accepted: 23 December 2019

Published online: 07 January 2020

\section{References}

1. Krishnasamy V, Otte J, Silbergeld E. Antimicrobial use in Chinese swine and broiler poultry production. Antimicrob Resist Infect Control. 2015;4:9.

2. Hvistendahl M. Public health. China takes aim at rampant antibiotic resistance. Science. 2012;336(6083):795.

3. Zhang Q-Q, Ying G-G, Pan C-G, Liu Y-S, Zhao J-L. Comprehensive evaluation of antibiotics emission and fate in the river basins of China: source analysis, multimedia modeling, and linkage to bacterial resistance. Environ Sci Technol. 2015;49(11):6772-82.

4. Vieira AR, Collignon P, Aarestrup FM, McEwen SA, Hendriksen RS, Hald T, et al. Association between antimicrobial resistance in Escherichia coli isolates from food animals and blood stream isolates from humans in Europe: an ecological study. Foodborne Pathog Dis. 2011;8(12):1295-301.

5. WHO. Antibiotic resistance: Multi-country public awareness survey. 2015. Report No.: 9241509813. Available from: http://www.who.int/drugresistance/en/.

6. Maron DF, Smith TJ, Nachman KE. Restrictions on antimicrobial use in food animal production: an international regulatory and economic survey. Global Health. 2013;9:48.

7. Xiao Y, Zhang J, Zheng B, Zhao L, Li S, Li L. Changes in Chinese policies to promote the rational use of antibiotics. PLOS Med. 2013;10(11):e1001556.

8. Ministry of Agriculture and Rural Affairs. Ministry of Agriculture Announcement 176, 193,278,560,1519,2292,2428,2638. Beijing. (2001-2018) [cited 2019 Nov 20th]. Available from: http://www.moa.gov.cn/nybgb/. Accessed 20 Nov 2019.

9. State Council. State Council Announcement 666: Regulations on administration of veterinary drugs. Beijing: 2016 [cited 2019 Nov 20th]. Available from: http://www.moa.gov.cn/govpublic/SYJ/201812/t201 81214_6164972.htm. Accessed 20 Nov 2019.

10. Van Boeckel TP, Brower C, Gilbert M, Grenfell BT, Levin SA, Robinson TP, et al. Global trends in antimicrobial use in food animals. Proc Natl Acad Sci. 2015;112(18):5649-54.

11. Nhung NT, Chansiripornchai N, Carrique-Mas JJ. Antimicrobial resistance in bacterial poultry pathogens: a review. Front Vet Sci. 2017:4:126.

12. Song $X$, Xie J, Zhang M, Zhang $Y$, Li J, Huang $Q$, et al. Simultaneous determination of eight cyclopolypeptide antibiotics in feed by high performance liquid chromatography coupled with evaporation light scattering detection. J Chromatogr B Anal Technol Biomed Life Sci. 2018;1076:103-9.

13. Sirdar MM, Picard J, Bisschop S, Gummow B. A questionnaire survey of poultry layer farmers in Khartoum state, Sudan, to study their antimicrobial awareness and usage patterns. Onderstepoort J Vet Res. 2012;79(1):E1-8.

14. Om C, McLaws ML. Antibiotics: practice and opinions of Cambodian commercial farmers, animal feed retailers and veterinarians. Antimicrob Resist Infect Control. 2016;5:42

15. Output of Major Livestock Products by City and County in Ningxia Province [Internet]. 2018 [cited Nov 20th, 2019]. Available from: http:/nxdata.com.cn/files_nx pub/htm//tjnj/2018/indexfiles/indexch.htm?1=1. Accessed 20 Nov 2019.

16. Lauritsen J, Bruus M. EpiData Entry (version 3.1). A comprehensive tool for validated entry and documentation of data. Odense: The EpiData Association; 2017. p. 270108

17. Ministry of Agriculture and Rural Affairs. Ministry of Agriculture Noticement (2017) 22. Beijing: 2017 [cited 2019 Nov 20th]. Available from: http://www.moa.gov.cn/ govpublic/SYJ/201706/t20170623_5726086.htm. Accessed 20 Nov 2019.

18. FDA U. General principles for evaluating the safety of compounds used in food-producing animals. 2006.

19. R Core Team. R: a language and environment for statistical computing. In: R Foundation for statistical computing. Vienna; 2018. URL https://www.Rproject.org/. 
20. Carrique-Mas JJ, Trung NV, Hoa NT, Mai HH, Thanh TH, Campbell Jl, et al. Antimicrobial usage in chicken production in the Mekong Delta of Vietnam. Zoonoses Public Health. 2015;62(Suppl 1):70-8.

21. Wongsuvan G, Wuthiekanun V, Hinjoy S, Day NP, Limmathurotsakul D. Antibiotic use in poultry: a survey of eight farms in Thailand. Bull World Health Organ. 2018:96(2):94-100.

22. Alimentarius C. Code of practice to minimize and contain antimicrobial resistance. CAC/RCP 61-2005 www codexalimentarius net/download/ standards/10213/CXP_061e pdf. 2005. Available from: www.fao.org/input/ download/standards/10213/CXP_061e.pdf

23. Lhermie G, Grohn YT, Raboisson D. Addressing Antimicrobiol resistance: an overview of priority actions to prevent suboptimal antimicrobial use in food-animal production. Front Microbiol. 2017;7:11.

24. Guetiya Wadoum RE, Zambou NF, Anyangwe FF, Njimou JR, Coman MM, Verdenelli MC, et al. Abusive use of antibiotics in poultry farming in Cameroon and the public health implications. Br Poult Sci. 2016;57(4):48393.

25. WHO. Integrated surveillance of antimicrobial resistance in foodborne bacteria: application of a One health approach. 2017. Available from: http:// who.int/foodsafety/areas_work/antimicrobial-resistance/en/.

26. Khan AA, Randhawa MA, Butt MS, Nawaz H. Impact of various processing techniques on dissipation behavior of antibiotic residues in poultry meat. J Food Process Preserv. 2016:40(1):76-82.

27. Christian A, Vivian Etsiapa B, Crystal Ngofi Z, Frank BO. Antibiotic Use in Poultry Production and Its Effects on Bacterial Resistance. IntechOpen. 2018; doi: https://doi.org/10.5772/intechopen.79371. Available from: https://www. intechopen.com/online-first/antibiotic-use-in-poultry-production-and-itseffects-on-bacterial-resistance.

28. Lu Y, Zhao H, Sun J, Liu Y, Zhou X, Beier RC, et al. Characterization of multidrug-resistant Salmonella enterica serovars Indiana and Enteritidis from chickens in eastern China. PLoS One. 2014;9(5):e96050.

29. Huang TM, Lin TL, Wu CC. Antimicrobial susceptibility and resistance of chicken Escherichia coli, Salmonella spp., and Pasteurella multocida isolates. Avian Dis. 2009:53(1):89-93.

30. WHO. Antimicrobial resistance global report on surveillance. Geneva; 2014. Available from: https://www.who.int/drugresistance/en/

31. Teillant A, Brower CH, Laxminarayan R. Economics of Antibiotic Growth Promoters in Livestock. In: Rausser GC, editor. Annual Review of Resource Economics, Vol 7. Annual Review of Resource Economics. 7. Palo Alto: Annual Reviews; 2015. p. 349-74.

32. Liu Q, Li J, Song X, Zhang M, Li E, Gao F, et al. Simultaneous determination of aminoglycoside antibiotics in feeds using high performance liquid chromatography with evaporative light scattering detection. RSC Adv. 2017; 7:1251-9.

33. Vandenberg LN. Low-dose effects of hormones and endocrine disruptors. Vitam Horm. 2014;94:129-65. https://doi.org/10.1016/B978-0-12-800095-3. 00005-5.

34. Strom G, Boqvist S, Albihn A, Fernstrom LL, Djurfeldt AA, Sokerya S, et al. Antimicrobials in small-scale urban pig farming in a lower middle-income country - arbitrary use and high resistance levels. Antimicrob Resist Infect Control. 2018;7:11.

35. Rousham EK, Unicomb L, Islam MA. Human, animal and environmental contributors to antibiotic resistance in low-resource settings: integrating behavioural, epidemiological and one health approaches. Proc R Soc B-Biol Sci. 2018:285(1876):9.

36. O'Neill J. Review on antimicrobial resistance antimicrobial resistance: tackling a crisis for the health and wealth of nations. London; 2014. Available from: https://amr-review.org/sites/default/files/AMR\%20Review\%2 OPaper\%20-\%20Tackling\%20a\%20crisis\%20for\%20the\%20health\%20and\%2 Owealth\%20of\%20nations_1.pdf

37. King LJ, Anderson LR, Blackmore CG, Blackwell MJ, Lautner EA, Marcus LC, et al. Executive summary of the AVMA one health initiative task force report. J Am Vet Med Assoc. 2008;233(2):259-61.

38. Statistical Yearbook of the Food And Agricultural Organization for the United Nations. World food and agriculture. 2013. Available from: http:// www.fao.org/3/i3107e/i3107e.pdf

39. Laxminarayan R, Duse A, Wattal C, Zaidi AK, Wertheim HF, Sumpradit N, et al. Antibiotic resistance-the need for global solutions. Lancet Infect Dis. 2013;13(12):1057-98
40. Tangcharoensathien V, Chanvatik S, Sommanustweechai A. Complex determinants of inappropriate use of antibiotics. Bull World Health Organ 2018;96(2):141-4.

41. Chauvin C, Croisier A, Tazani F, Balaine L, Eono F, Salaun-Huneau A, et al. Utilisation des antibiotiques en filière cunicole: Enquête en élevages 20092010. In: Journées de la Recherche cunicole; 2011. p. 22-3.

42. Schulze-Geisthovel SV, Tappe EV, Schmithausen RM, Lepkojis J, Rottgen K, Petersen B. Survey on the risk awareness of german pig and cattle farmers in relation to dealing with MRSA and antibiotics. Infect Ecol Epidemiol. 2016;6:29817

\section{Publisher's Note}

Springer Nature remains neutral with regard to jurisdictional claims in published maps and institutional affiliations.
Ready to submit your research? Choose BMC and benefit from:

- fast, convenient online submission

- thorough peer review by experienced researchers in your field

- rapid publication on acceptance

- support for research data, including large and complex data types

- gold Open Access which fosters wider collaboration and increased citations

- maximum visibility for your research: over $100 \mathrm{M}$ website views per year

At BMC, research is always in progress.

Learn more biomedcentral.com/submissions 